\title{
Cytotoxic Effect of Some Mycotoxins and their Combinations on Human Peripheral Blood Mononuclear Cells as Measured by the MTT Assay
}

\author{
S. Stoev ${ }^{*}, 1$, S. Denev ${ }^{2}$, M. Dutton ${ }^{3}$ and B. Nkosi ${ }^{3}$ \\ ${ }^{I}$ Department of General and Clinical Pathology, Faculty of Veterinary Medicine, Trakia University, Students Campus, \\ 6000 Stara Zagora, Bulgaria \\ ${ }^{2}$ Department of Microbiology, Faculty of Agriculture, Trakia University, Students Campus, 6000 Stara Zagora, Bulgaria \\ ${ }^{3}$ Food, Environment and Health Research Group, Faculty of Health Science, University of Johannesburg, Doornfontein \\ 2028, Gauteng, P.O. Box 17011, South Africa
}

\begin{abstract}
The objective of this study was to assess cytotoxic effects of ochratoxin A (OTA), penicillic acid (PA), citrinin (CIT), fumonisin B1 (FB1) and their combinations (as naturally occur in real practice) on human peripheral blood mononuclear cells (PBM) using a simple and cheap "in vitro" cytotoxicity test as MTT assay. A stronger suppression on metabolic activity of phytohaemagglutinin-p (PHA)-stimulated PBM was found for a mixture of the following mycotoxins: OTA, CIT and FB1 as compared to any single mycotoxin. PA was found to increase significantly the metabolic activity of the same cells in concentrations above $111 \mathrm{mg} / \mathrm{L}$. There is no "in vitro" synergistic effect between OTA and PA as measured by MTT assay, unlike the strong "in vivo" synergistic effect between the same mycotoxins. The MTT bioassay is not appropriate to measure cell viability and cell proliferation, especially if metabolic activity of the cells is increased as was observed in PA treated human blood mononuclear cells or if the same is decreased. The doses which exert approximately 50\% suppression of metabolic activity of PHA-stimulated human blood mononuclear cells (LD50) are determined to be as follows: for OTA -1.56 to $3.125 \mathrm{mg} / \mathrm{L}$, CIT -62.5 to $111 \mathrm{mg} / \mathrm{L}$ and FB1 -62.5 to $500 \mathrm{mg} / \mathrm{L}$. Cell viability (proliferation) of all mycotoxin treated blood mononuclear cells was significantly decreased at the highest concentrations of mycotoxins, but this decrease was significantly stronger for OTA-treated cells and especially for different mixtures of mycotoxins.
\end{abstract}

Keywords: Ochratoxin A, Penicillic acid, Citrinin, Fumonisin B1, MTT assay, Cytotoxicity.

\section{INTRODUCTION}

Fumonisins are mycotoxins produced by Fusarium verticillioides ( $F$. moniliforme), Fusarium proliferatum and related Fusarium species found mainly in corn (maize) [1]; whereas, OTA is mainly produced by A. ochraceus and $P$. viridicatum (verrucosum), that often contaminate various animal and human food items stored for long periods of time. PA can be produced by $P$. aurantiogriseum strains and the same ochratoxinogenic fungi from the Aspergillus ochraceus group, which are the major producers of OTA in warmer climates [2]. CIT is produced mainly by Penicillium citrinum, which is also a storage fungus. However, only scarce data are available regarding combined exposures to OTA, CIT, FB1 and PA, which might spontaneously occur under field conditions $[2,3]$. The same mycotoxins were recently found in high contamination levels (especially FB1 and PA) in most feeds originating from farms with mycotoxic porcine or avian nephropathy [4]. Mycological investigations of animal feeds in Bulgaria revealed P. aurantiogriseum strains [2], which are potent producers of PA. On the other hand OTA, CIT and FB1 are reportedly nephrotoxic and involved in some cases of nephropathy in various countries $[2,4,5]$.

*Address correspondence to this author at the Department of General and clinical pathology, Faculty of Veterinary Medicine, Trakia University, Students campus, 6000 Stara Zagora, Bulgaria; Tel: +35942 670540;

E-mail: stoev@uni-sz.bg
The estimated amounts of OTA in Bulgarian feeds from farms with nephropathy were at least 5-fold less (100-200 $\mathrm{ppb}$ ) than that presented as the explanation for Danish mycotoxic porcine (MPN) or chicken (MCN) nephropathy $[2,3,6]$. The conclusion is that the animal's intake of OTA is much lower than that shown to be necessary [7], even for less severe symptomatology, by all the classic experimental studies in Denmark. It seems, therefore, that Bulgarian porcine/chicken nephropathy may have a multitoxic aetiology because it cannot be explained by the concentration of OTA alone [2, 3]. In addition, these low feed- and serum levels of OTA in MPN-affected farms are very similar and comparable to those found in food and blood of humans suffering from Balkan Endemic Nephropathy (BEN) - a problematic disease in Bulgaria and other Balkan countries [8,9], which suggest a common aetiology in both diseases - BEN and MPN [10]. Recently, we have induced porcine- as well as chicken nephropathies using a mouldy diet containing very low levels of OTA (180$300 \mathrm{ppb}$ ) in combination with PA [11-13]. The more potent toxicity of OTA in these studies might be due to synergy when OTA is simultaneously administered with PA, as reported in mice $[14,15]$ and in poultry [16]. Such synergism between OTA and other mycotoxins (as PA, CIT or FB1) under field conditions may be responsible for the spontaneous MPN [2,6] and MCN [3] in Bulgaria, which can be caused by relatively low contamination levels of OTA 
in feed (mean $207.10 \mathrm{ppb}$ for 1993, $114.06 \mathrm{ppb}$ for 1994 and $196.2 \mathrm{ppb}$ for 1997).

Recently, the multimycotoxin etiology of MPN/MCN in Bulgaria was confirmed as high contamination levels of PA (mean $838.6 \mathrm{ppb}, 88 \%$ positives) and FB1 (mean $5564.1 \mathrm{ppb}$, $96 \%$ positives) in Bulgarian feed samples from farms with mycotoxic porcine nephropathy were found; whereas, the levels of OTA (mean $188.8 \mathrm{ppb}, 100 \%$ positives) in the same feeds were consecutively lower [4]. A similar multimycotoxin etiology was also found for South African MPN as the same mixture of mycotoxins (mean $67.8 \mathrm{ppb}$ for OTA, 83.3\% positives; $149.2 \mathrm{ppb}$ for PA, $41.7 \%$ positives; $5046.2 \mathrm{ppb}$ for FB1, $80 \%$ positives) was found in South African feed samples from pig farms with nephropathy problems [4]. Upon considering this circumstance, it seems that the risk assessment for animals and humans potentially exposed to multi-mycotoxins suffers from the lack of adequate information, because synergistic or antagonistic interaction between various mycotoxins are often present, but not taken into account. Therefore, it was necessary to carry out some field and laboratory investigations in relation to synergistic effects of the same mycotoxins.

In the present study the combination of mycotoxins, naturally occurring in foodstuffs and especially in feeds from farms with high incidences of MPN or MCN, was tested for cytotoxicity using a MTT assay. This straightforward premise should increase our knowledge about toxicity of the same combinations of mycotoxins. Generally, the purpose of the present study was to determine whether a simple and cheap "in vitro" cytotoxicity test (MTT assay) may help predicting "in vivo" toxicity of mycotoxins and their combinations that are obviously naturally occurring, yet are neglected at the present time in human and animal risk assessment. At the same time, expensive "in vivo" animal studies could be reduced to some extent. The objective of this study was to assess cytotoxic effects of OTA, CIT, PA, FB1 and their combinations on human PBM as the concentrations of OTA were about 10 times lower than the concentrations of the other mycotoxins as it naturally occurs in real practice.

\section{MATERIALS AND METHODS}

\section{Chemicals and Mycotoxins}

Mycotoxins: OTA, CIT and FB1, Histopaque 1119, MTT Assay Kit [3-(4,5-dimethylthiazol-2-yl)-2,5-diphenyltetrazolium bromide], phosphate buffered saline (PBS) - $\mathrm{pH} 7.4$, RPMI 1640 (with L-glutamine), Histopaque 1119, phytohaemagglutinin-p (PHA), dimethylsulphoxide (DMSO), foetal bovine serum (FBS), penicillin/streptomycin (Penstrep) and Trypan blue were obtained from Sigma Bioscience (St Louis, MO, USA). PA was obtained from A.G. Scientific, Inc. (San Diego, CA, USA).

\section{Isolation and Purification of Blood PBM}

Purification of PBM was performed according to Meky et al. [17] with a little modification. Blood was collected from four healthy donors (volunteers) using $10 \mathrm{ml}$ heparin tubes and mixed with an equal volume of complete culture medium - CCM (RPMI 1640 medium, supplemented with $10 \% \mathrm{FBS}, 100 \mathrm{U} / \mathrm{ml}$ penicillin and $100 \mathrm{mg} / \mathrm{L}$ streptomycin). Diluted blood from each donor was then gently overlaid on Histopaque 1119, centrifuged at $800 \times \mathrm{g}$ for $30 \mathrm{~min}$, and the interface (middle) layer consisting of mononuclear cells carefully collected with a sterile pipette. Cells were then washed twice with an equal quantity of RPMI 1640 medium, and each time centrifuged at $800 \times \mathrm{g}$ for $5 \mathrm{~min}$. After the second washing, cells $\left(1 \times 10^{6}\right.$ cells $\left./ \mathrm{ml}\right)$ were resuspended gently in CCM.

\section{Counting of Cells Using Neubauer Haemocytometer and Trypan Blue Staining}

Cell concentrations were determined as the cells were mixed with $0.2 \%$ trypan blue (dilution factor 5 ) and counted by a Neubauer haemocytometer using the following procedure: $10 \mu \mathrm{l}$ of cell suspension mixed with $40 \mu 10.2 \%$ trypan blue and $10 \mu \mathrm{l}$ of the same mixture was transferred to both chambers of Neubauer haemocytometer.

The percentage of cell viability was calculated via the formula:

$\%$ cell viability $=$ viable cells $($ unstained) $/$ total number of cells $\times 100$.

Cell viability before the cytotoxicity experiment was above $98 \%$ (98.4\%).

\section{Experimental Design}

A $100 \mu 1$ cell suspension was added to each well of a 96well microtitre plate (Corning Cell Wells ${ }^{\mathrm{TM}}$, Corning, USA). Proliferation of human PBM was stimulated as PHA $(5 \mathrm{mg} / \mathrm{L})$ was added to each well.

The four examined mycotoxins (OTA, CIT, FB1 and PA) were dissolved in DMSO and subsequently diluted with $\mathrm{CCM}$ in ratio 1:10 (mycotoxin in DMSO : $\mathrm{CCM}$ ) in order to make a stock initial solution of $0.1 \mathrm{mg} / \mathrm{ml}$ for OTA and $1 \mathrm{mg} / \mathrm{ml}$ for CIT, PA and FB1. Two serial dilutions (1:2 and 1:3) for each mycotoxin, and combination of mycotoxins, were performed in order to ensure their final concentration in cell culture in the wells. For mixture 1, the concentrations of mycotoxins (OTA, CIT, PA and FB1) were 4 times lower than those of any single mycotoxin in order to keep the same volume of cell suspension in the wells. For mixture 2 (OTA, CIT and FB1), we used an equivalent volume of CCM to substitute for the absence of PA (Figs. 1, 2).

For control wells, serial dilutions were made with the same quantity of CCM (including the same quantity of mycotoxin diluent $-10 \%$ of DMSO) in the same way. All plates then were shaken for $1 \mathrm{~min}$ in a plate shaker (TTS 3 Digital Yellow line, MERK) and incubated for $48 \mathrm{~h}$ at $37^{\circ} \mathrm{C}$ in $5 \% \mathrm{CO}_{2}$-buffered and a humidified incubator (Forma Scientific $\mathrm{CO}_{2}$ Water Jacketed Incubator).

For ensuring reliability, the assay was done in triplicate for each concentration of mycotoxins in four different experiments.

\section{MTT Assay}

MTT assay was performed according to Meky et al. [17] and Mosmann [18] with a little modification in order to determine the cytotoxic potentials of the toxins and their combinations on the PBM.

MTT tetrazolium salt was dissolved in $0.14 \mathrm{M}$ PBS $(\mathrm{pH}$ 7.4) at $5 \mathrm{mg} / \mathrm{ml}$ and filtered using a $0.22 \mu \mathrm{M}$ pore size. After a $48 \mathrm{~h}$ incubation period, $30 \mu \mathrm{l}$ MTT solution was added to 


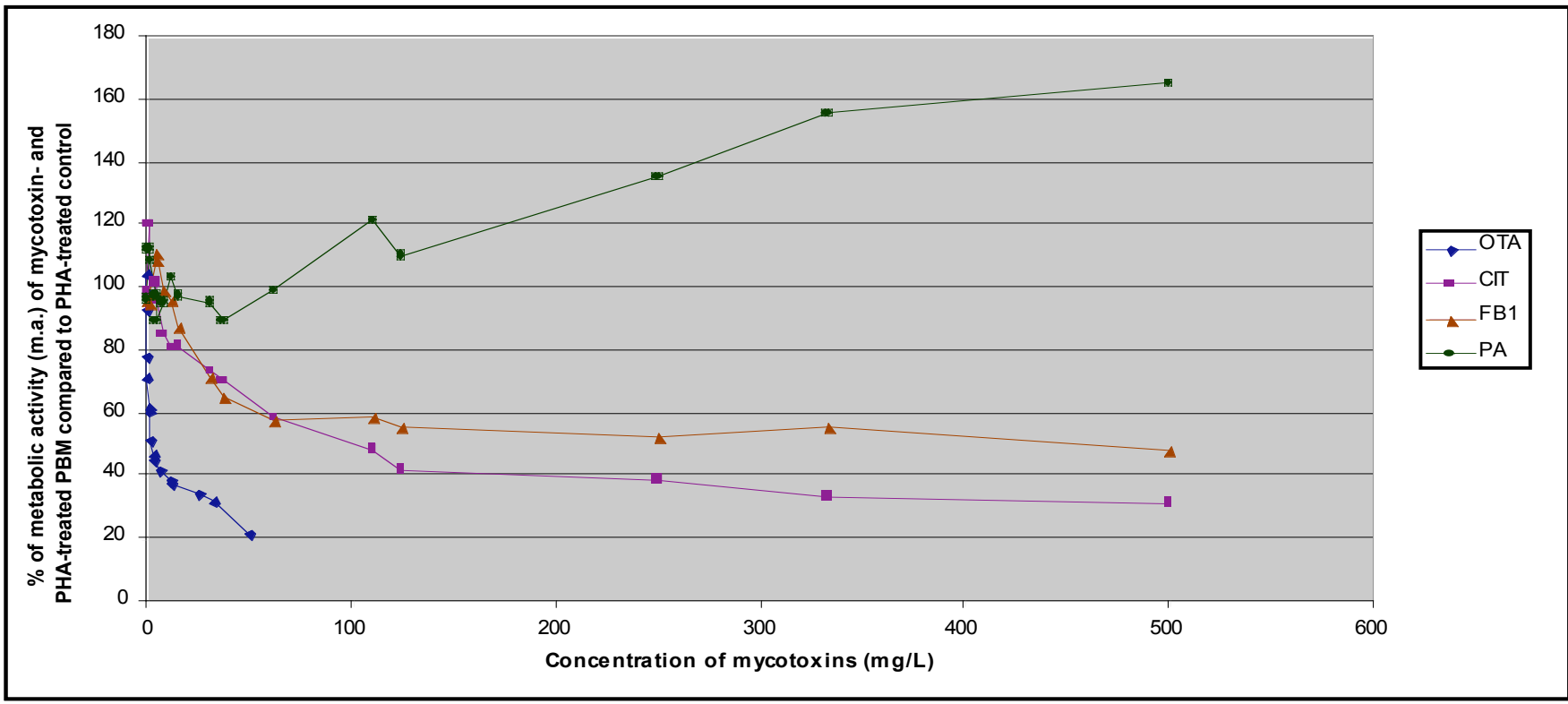

\begin{tabular}{|c|c|c|c|c|c|c|c|c|c|c|c|c|c|c|c|c|}
\hline OTA $^{\#}(\mathrm{mg} / \mathrm{L})$ & 50 & 33.3 & 25 & 12.5 & 11.1 & 6.25 & 3.7 & 3.125 & 1.56 & 1.23 & 0.78 & 0.41 & 0.39 & 0.137 & 0.045 & 0.015 \\
\hline \multirow{2}{*}{ m.a. (\%) } & 21.2 & 31.3 & 34.1 & 37.6 & 38.7 & 41.5 & 44.8 & 46.7 & 51.5 & 60.2 & 61.3 & 70.8 & 78.1 & 92.8 & 103.9 & 98.4 \\
\hline & \pm 1.8 & \pm 2.3 & \pm 1.6 & \pm 1.8 & \pm 3.2 & \pm 2.5 & \pm 3.4 & \pm 1.9 & \pm 2.1 & \pm 1.2 & \pm 2.6 & \pm 2.4 & \pm 2.2 & \pm 3.6 & 3.8 & 3.1 \\
\hline L) & 500 & 333 & 250 & 125 & 111 & 62.5 & 37 & 31.25 & 15.6 & 12.3 & 7.8 & 4.1 & 3.9 & 1.37 & 0.45 & 0.15 \\
\hline \multirow{2}{*}{ m.a. (\%) } & 31.1 & 33.2 & 38.3 & 41.8 & 48.1 & 58.1 & 70.1 & 73.1 & 81.4 & 80.4 & 85.1 & 96.3 & 101.5 & 94.2 & 120.3 & 98.4 \\
\hline & $6^{a, c}$ & $\pm 2.4^{a, c}$ & $\pm 2.1^{\mathrm{a}, \mathrm{c}}$ & $\pm 2.8^{\mathrm{a}, \mathrm{c}}$ & $\pm 2.8^{\mathrm{a}, \mathrm{c}}$ & $\pm 3.4^{\mathrm{a}}$ & $\pm 1.8^{\mathrm{a}}$ & $\pm 21^{\mathrm{a}}$ & $\pm 26^{a}$ & \pm 3.9 & \pm 1.8 & \pm 2.1 & \pm 2.2 & $\begin{array}{l}+2.8 \\
\end{array}$ & $\begin{array}{l}+2.6 \\
\end{array}$ & +1.8 \\
\hline FB1 & 500 & 333 & 250 & 125 & 111 & 62.5 & 37 & 31.25 & 15.6 & 12.3 & 7.8 & 4.1 & 3.9 & 1.37 & 0.45 & 0.15 \\
\hline \multirow{2}{*}{ m.a. (\%) } & 48.1 & 55.3 & 52.4 & 55.6 & 58.2 & 57.4 & 65.4 & 71.2 & 87.2 & 95.4 & 99.4 & 111.3 & 108.3 & 98.1 & 95.3 & 96.1 \\
\hline & $\pm 2.6^{a, b}$ & $\pm 3.6^{a, b}$ & $\pm 3.2^{a, b}$ & $\pm 4.1^{\mathrm{a}, \mathrm{b}}$ & $\pm 1.9^{\mathrm{a}, \mathrm{b}}$ & $\pm 2.6^{\mathrm{a}}$ & $\pm 2.2^{\mathrm{a}}$ & $\pm 2.8^{\mathrm{a}}$ & \pm 2.4 & \pm 1.8 & \pm 2.8 & \pm 4.4 & \pm 3.1 & \pm 2.2 & \pm 2.6 & \pm 2.3 \\
\hline PA (mg/L) & 500 & 333 & 250 & 125 & 111 & 62.5 & 37 & 31.25 & 15.6 & 12.3 & 7.8 & 4.1 & 3.9 & 1.37 & 0.45 & 0.15 \\
\hline \multirow{2}{*}{ m.a. (\%) } & 165.3 & 155.2 & 135.4 & 110.2 & 121.2 & 98.7 & 89.1 & 95.2 & 97.3 & 103.1 & 95.2 & 89.3 & 97.4 & 108.3 & 112.2 & 96.4 \\
\hline & \pm 4 & $8^{\circ}$ & & $+85^{b,}$ & $\pm 9.2^{\mathrm{b}}$ & $\pm 7.1^{\mathrm{b}, \mathrm{c}}$ & $\pm 8.4^{6,}$ & $\pm 6.2^{\mathrm{b}, \mathrm{c}}$ & $\pm 9.1^{b}$ & \pm 6.3 & \pm 8.1 & \pm 9.2 & \pm 6.1 & \pm 4.2 & \pm 9.1 & \pm 5.2 \\
\hline
\end{tabular}

Fig. (1). The effect of mycotoxins OTA, CIT, FB1 and PA on metabolic activity of PHA-stimulated PBM measured by MTT assay. Values presented are the mean ( \pm standard error of the mean) of 3 samples in 4 different experiments representing percentage change from the control PHA-treated PBM.

${ }^{a}$ Significant difference $(\mathrm{p}<0.05)$ compared with the respective value of PA-treated cells.

${ }^{\mathrm{b}}$ Significant difference $(\mathrm{p}<0.05)$ compared with the respective value of CIT-treated cells.

${ }^{\mathrm{c}}$ Significant difference $(\mathrm{p}<0.05)$ compared with the respective value of FB1-treated cells.

\# Concentrations of OTA exposure are 10 times lower because of the stronger cytotoxic effect of this mycotoxin; therefore, the m.a. values of OTA-treated cells can not be directly compared with those of CIT, FB1 and PA treated cells. It can be supposed that they are significantly lower upon considering the 10 -fold lower levels of OTA-exposure.

each well, mixed thoroughly via plate shaker for $1 \mathrm{~min}$, and all plates were again placed in the same incubator. After $4 \mathrm{~h}$ incubation at $37^{\circ} \mathrm{C}$ in $5 \% \quad \mathrm{CO}_{2}$-buffered and humidified incubator, a $100 \mu \mathrm{LMSO}$ was added to each well and mixed thoroughly in order to dissolve the formed blue crystals of formazan. All plates were then shaken for 1 min and incubated for $2 \mathrm{~h}$. The optical density (OD) of wells was measured by Microplate Reader (Benchmark Plus Micrfoplate Spectrophotometer) at wavelength $560 \mathrm{~nm}$ and $620 \mathrm{~nm}$. The effect of mycotoxin treatment on mitochondrial metabolic activity was calculated as \% of metabolic activity of mycotoxin treated cells against control cells using the formula:

$\%$ of metabolic activity $=$ OD of mycotoxin-treated wells / OD of control wells $\times 100$.
The percent of metabolic activity of mycotoxin- and PHA-treated PBM was calculated as a percent change from the control PHA-treated PBM.

\section{Cell Proliferation}

The effect of mycotoxins OTA, CIT, FB1, PA on cell proliferation of PHA-stimulated human PBM was calculated after $48 \mathrm{~h}$ using trypan blue staining and a Neubauer haemocytometer. The number of viable cell (unstained) was only calculated in the cell suspension exposed to the highest concentrations of various mycotoxins (alone and in the mixtures). Values presented are the mean ( \pm standard error of 3 samples in 4 different experiments) percentage of the proliferation from control PHA-treated PBM (only viable cells were counted).

$\%$ cell proliferation $=$ viable mycotoxin-treated cells $/$ viable control cells $\times 100$. 


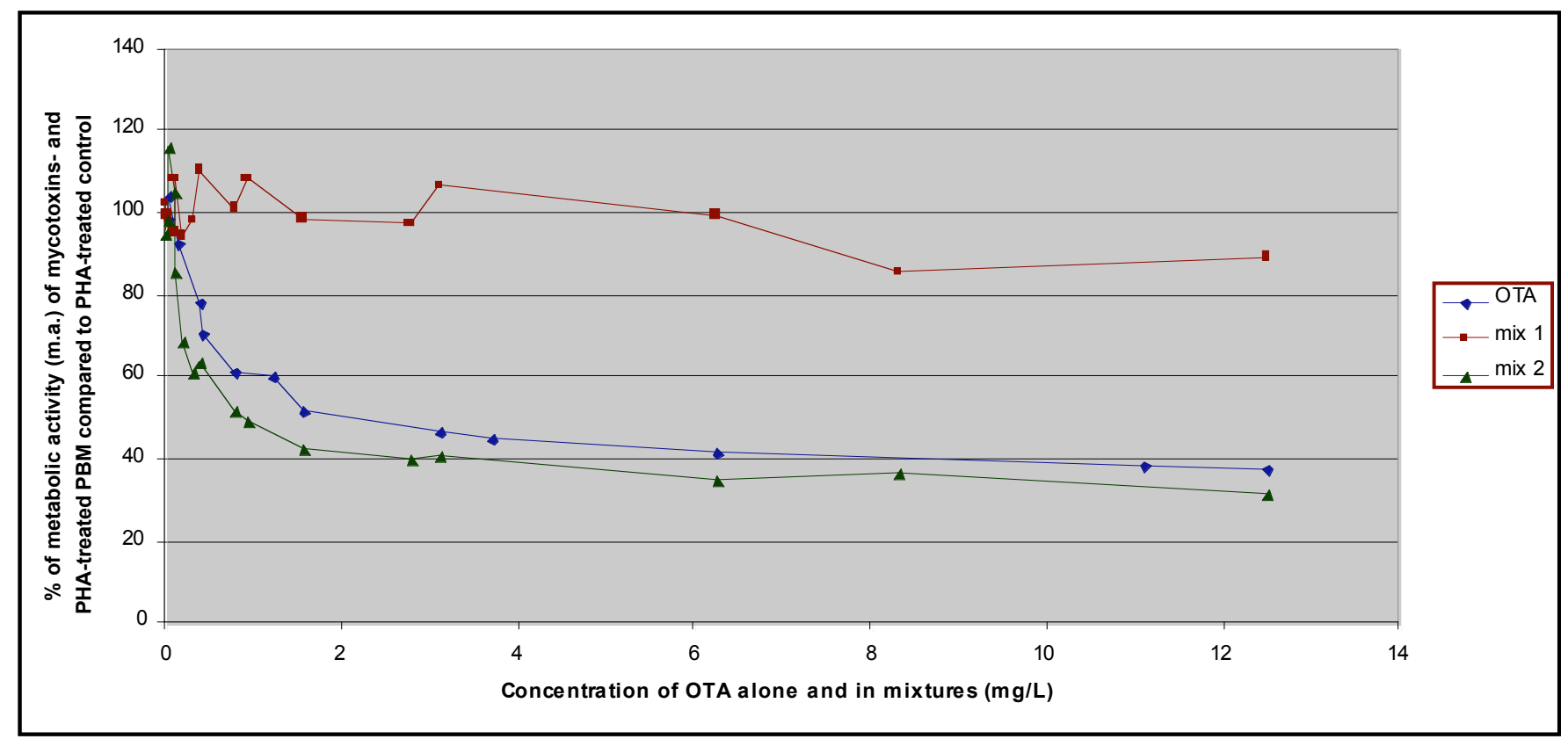

\begin{tabular}{|c|c|c|c|c|c|c|c|c|c|c|c|c|c|c|c|c|}
\hline $\begin{array}{c}\text { OTA } \\
\text { (mg/L) }\end{array}$ & 12.5 & 11.1 & 6.25 & 3.7 & 3.125 & 1.56 & 1.23 & 0.78 & 0.41 & 0.39 & 0.137 & 0.045 & 0.015 & & & \\
\hline m.a. (\%) & $\begin{array}{c}37.6 \\
\pm 1.8^{\mathrm{a}}\end{array}$ & $\begin{array}{l}38.7 \\
\pm 3.2\end{array}$ & $\begin{array}{r}41.5 \\
\pm 2.5^{\mathrm{a}}\end{array}$ & $\begin{array}{l}44.8 \\
\pm 3.4\end{array}$ & $\begin{array}{c}46.7 \\
\pm 1.9^{a}\end{array}$ & $\begin{array}{r}51.5 \\
\pm 2.1^{\mathrm{a}}\end{array}$ & $\begin{array}{l}60.2 \\
\pm 1.2\end{array}$ & $\begin{array}{r}61.3 \\
\pm 2.6^{\mathrm{a}}\end{array}$ & $\begin{array}{l}70.8 \\
\pm 2.4\end{array}$ & $\begin{array}{c}78,1 \\
\pm 2,2^{a}\end{array}$ & $\begin{array}{l}92.8 \\
\pm 3.6\end{array}$ & $\begin{array}{c}103.9 \\
\pm 3.8\end{array}$ & $\begin{array}{l}98.4 \\
\pm 3.1\end{array}$ & & & \\
\hline $\begin{array}{c}\text { Mix 1 } \\
\text { (mg/L) } \\
\text { OTA [CIT, } \\
\text { FB1, PA] }\end{array}$ & $\begin{array}{c}12,5 \\
{[125]}\end{array}$ & $\begin{array}{c}8.325 \\
{[83.25]}\end{array}$ & $\begin{array}{c}6.25 \\
{[62.5]}\end{array}$ & \begin{tabular}{|c}
3.125 \\
{$[31.25]$}
\end{tabular} & $\begin{array}{c}2.775 \\
{[27.75]}\end{array}$ & $\begin{array}{c}1.56 \\
{[15.6]}\end{array}$ & $\begin{array}{l}0.925 \\
{[9.25]}\end{array}$ & $\begin{array}{l}0.78 \\
{[7.8]}\end{array}$ & $\begin{array}{l}0.39 \\
{[3.9]}\end{array}$ & $\begin{array}{l}0.3083 \\
{[3.083]}\end{array}$ & $\begin{array}{l}0.195 \\
{[1.95]}\end{array}$ & $\begin{array}{l}0.1027 \\
{[1.027]}\end{array}$ & $\begin{array}{l}0.0975 \\
{[0.975]}\end{array}$ & {$\left[\begin{array}{l}0.0342 \\
{[0.342]}\end{array}\right.$} & $\begin{array}{l}0.0114 \\
{[0.114]}\end{array}$ & $\begin{array}{l}0.0038 \\
{[0.038]}\end{array}$ \\
\hline m.a. (\%) & $\begin{array}{c}89.4 \\
\pm 3.2^{\mathrm{b}}\end{array}$ & $\begin{array}{l}85.3 \\
\pm 4.1\end{array}$ & $\begin{array}{c}99.5 \\
\pm 5.2^{\mathrm{b}}\end{array}$ & $\begin{array}{l}106.4 \\
\pm 6.1^{b}\end{array}$ & $\begin{array}{l}97.3 \\
\pm 7.2\end{array}$ & $\begin{array}{r}98.4 \\
\pm 5.1^{\mathrm{b}}\end{array}$ & $\begin{array}{c}108.4 \\
\pm 8.9\end{array}$ & $\begin{array}{l}101.2 \\
\pm 9.8^{b}\end{array}$ & $\begin{array}{l}110.4 \\
\pm 8.6^{\mathrm{b}}\end{array}$ & $\begin{array}{l}98.3 \\
\pm 6.4\end{array}$ & $\begin{array}{l}94.2 \\
\pm 8.2\end{array}$ & $\begin{array}{c}108.3 \\
\pm 7.4\end{array}$ & $\begin{array}{l}95.2 \\
\pm 5.5\end{array}$ & $\begin{array}{l}98.4 \\
\pm 5.4\end{array}$ & $\begin{array}{l}99.2 \\
\pm 6.1\end{array}$ & $\begin{array}{c}102.5 \\
\pm 4.2\end{array}$ \\
\hline $\begin{array}{c}\text { Mix 2 } \\
\text { (mg/L) } \\
\text { OTA [CIT, } \\
\text { FB1] }\end{array}$ & $\begin{array}{c}12.5 \\
{[125]}\end{array}$ & $\begin{array}{c}8.325 \\
{[83.25]}\end{array}$ & $\begin{array}{c}6.25 \\
{[62.5]}\end{array}$ & $\begin{array}{c}3.125 \\
{[31.25]}\end{array}$ & $\begin{array}{c}2.775 \\
{[27.75]}\end{array}$ & $\begin{array}{c}1.56 \\
{[15.6]}\end{array}$ & $\begin{array}{l}0.925 \\
{[9.25]}\end{array}$ & $\begin{array}{l}0.78 \\
{[7.8]}\end{array}$ & $\begin{array}{l}0.39 \\
{[3.9]}\end{array}$ & $\begin{array}{l}0.3083 \\
{[3.083]}\end{array}$ & $\begin{array}{l}0.195 \\
{[1.95]}\end{array}$ & $\begin{array}{l}0.1027 \\
{[1.027]}\end{array}$ & $\begin{array}{l}0.0975 \\
{[0.975]}\end{array}$ & $\begin{array}{l}0.0342 \\
{[0.342]}\end{array}$ & $\begin{array}{l}0.0114 \\
{[0.114]}\end{array}$ & $\begin{array}{l}0.0038 \\
{[0.038]}\end{array}$ \\
\hline m.a. (\%) & $\begin{array}{c}31.2 \\
\pm 1.4^{\mathrm{a}, \mathrm{b}}\end{array}$ & $\begin{array}{r}36.2 \\
\pm 1.8^{\mathrm{a}}\end{array}$ & $\begin{array}{c}35.1 \\
\pm 1.6^{\mathrm{a}}\end{array}$ & $\begin{array}{r}41.2 \\
\pm 2.3^{\mathrm{a}}\end{array}$ & $\begin{array}{c}39.6 \\
\pm 2.4^{a}\end{array}$ & $\begin{array}{c}42.3 \\
\pm 2.8^{\mathrm{a}, \mathrm{b}}\end{array}$ & $\begin{array}{c}48.9 \\
\pm 1.9^{\mathrm{a}}\end{array}$ & $\begin{array}{c}52.1 \\
\pm 1.2^{\mathrm{a}, \mathrm{b}}\end{array}$ & $\begin{array}{c}63.6 \\
\pm 2.8^{\mathrm{a}, \mathrm{b}}\end{array}$ & $\begin{array}{c}61.4 \\
\pm 3.4^{\mathrm{a}}\end{array}$ & $\begin{array}{c}68.4 \\
\pm 4.6^{\mathrm{a}}\end{array}$ & $\begin{array}{c}85.6 \\
\pm 5.2^{\mathrm{a}}\end{array}$ & $\begin{array}{c}105.4 \\
\pm 6.8\end{array}$ & $\begin{array}{c}116.5 \\
\pm 7.2\end{array}$ & $\begin{array}{r}98.4 \\
\pm 6.5\end{array}$ & $\begin{array}{r}95.2 \\
\pm 4.8\end{array}$ \\
\hline
\end{tabular}

Fig. (2). The effect of mycotoxin mixtures 1 (mix 1 - OTA, CIT, FB1 and PA), mixture 2 (mix 2 - OTA, CIT and FB1) and OTA alone on metabolic activity of PHA-stimulated PBM measured by MTT assay. Values are the mean ( \pm standard error) of 3 samples in 4 different experiments representing percentage change from the control PHA-treated PBM.

${ }^{a}$ Significant difference $(\mathrm{p}<0.05)$ compared with the respective value of mix 1-treated cells.

${ }^{\mathrm{b}}$ Significant difference $(\mathrm{p}<0.05)$ compared with the respective value of only OTA-treated cells.

Mix 1 (with PA) - Mixture 1, containing OTA, CIT, FB1 and PA in relevant concentrations.

Mix 2 (without PA) - Mixture 2, containing OTA, CIT and FB1 in relevant concentrations.

\section{Statistical Analysis}

The non-parametric Mann-Whitney-U-test in addition to Student's t-test was used to estimate the significance of the differences between the mean values of the various parameters as appropriate.

Dose response curves are computer plotted by converting data mean values to percent of metabolic activity against controls and using various concentrations of mycotoxins as well as their combinations in order to compare the toxicity of different mycotoxins and mixture of mycotoxins in a graphic way.

\section{RESULTS}

The OD values obtained by the MTT assay showed that OTA is the strongest suppressor of metabolic activity of human PBM, whereas CIT followed by FB1 have significantly lower suppression on metabolic activity of PHA-stimulated PBM. In contrast, PA increases significantly metabolic activity of PHA-stimulated human PBM (Fig. 1). By comparing the action of the both mixtures of mycotoxins on human PHA-stimulated PBM, it was found that mixture 1 (containing all examined mycotoxins) have significantly $(\mathrm{p}<$ 0.05 ) lower inhibitory effect on metabolic activity of human PBM than mixture 2 (containing the same mycotoxins without PA in the same concentrations) (Fig. 2). 
When comparing suppressive effects of the most toxic mycotoxin OTA and mixture 2, it was clear that mixture 2 has stronger suppressive effects on metabolic activity of human PBM than OTA or any single mycotoxin (Fig. 2). The combined effect of mycotoxins of mixture 2 was found to be much stronger, when compared to any single mycotoxin. On the other hand OTA was found to have much stronger $(p<0.001)$ suppressive effect on metabolic activity of human PBM when used alone, than in combination with PA (as it is in mixture 1) (Fig. 2). The doses which exert approximately $50 \%$ suppression of metabolic activity of PHA-stimulated human PBM (LD50) are determined to be as follow: for OTA -1.56 to $3.12 \mathrm{mg} / \mathrm{L}$, for CIT -62.5 to $111 \mathrm{mg} / \mathrm{L}$, for FB1 -62.5 to $500 \mathrm{mg} / \mathrm{L}$, for mixture $2-0.78$ to $0.925 \mathrm{mg} / \mathrm{L}$ OTA in combination with $7.8-9.25 \mathrm{mg} / \mathrm{L}$ of CIT and FB1 (Figs. 1, 2). For mixture 1, there was only slight suppression on metabolic activity of PHA-stimulated PBM in the highest concentrations of the same combinations of mycotoxins; whereas, PA significantly increases metabolic activity of PHA-stimulated PBM in concentrations above $111 \mathrm{mg} / \mathrm{L}$ (Fig. 1).

By comparing the number of viable cells treated with the highest concentrations of mycotoxins after $48 \mathrm{~h}$, it was established that the percent cell proliferation of all mycotoxin-treated cells was significantly decreased; however, this was more evident for OTA-treated cells (exposed to 10 times lower concentrations in comparison to all other mycotoxins) and especially for mix 1- and mix 2treated cells (Table 1). This decrease was significantly lower for PA- and CIT-treated cells, and especially for FB1-treated cells exposed to 10 times higher mycotoxin levels in comparison to OTA-levels. This indicates that there is a significant increase of metabolic activity of PA-treated cells (measured per cell); whereas, the decrease in metabolic activity in OTA, CIT and FB1 treated PBM is mainly due to decreased numbers of viable cells treated by the same mycotoxins. There is a slight contribution by a simultaneous decrease in metabolic activity of viable cells, which was statistically significant only for OTA-treated PBM (Table 1).

\section{DISCUSSION}

The analyses of our results clearly indicates that both studied mixtures of mycotoxins have a stronger cytotoxic effect on cell viability/proliferation, than any single mycotoxin. However, the designed study doesn't clearly differentiate exactly the combined effects of mycotoxins synergistic or additive. Nevertheless, it can be seen that OTA alone $(0.78 \mathrm{mg} / \mathrm{L})$ has a significantly lower cytotoxic effect than in combination with statistically non-cytotoxic levels of FB1 and CIT $(7.8 \mathrm{mg} / \mathrm{L})$.

The high variability of some LD50 values as this one of FB1 (62.5 - $500 \mathrm{mg} / \mathrm{L})$ could be explained by different sensitivity of PBM coming from various donors to cytotoxic effect of studied mycotoxins. The use of cell lines, instead PBM cultures, could perhaps reduce this variability.

The stronger cytotoxic effect of different combinations of mycotoxin (OTA, CIT and FB1), observed in the present experiment is in line with some other "in vivo" and "in vitro" studies from the literature. This synergistic effect between OTA and FB1, previously proved "in vitro" $[19,20]$, is in agreement with "in vivo" data [21]. The synergism of FB1 and OTA could be related to both toxins impairing protein synthesis and increasing lipid peroxidation, thus producing reactive oxygen species [22-24]. In addition, OTA and FB1 reportedly induce "in vitro" and "in vivo" degenerative changes in rat kidney [25-28], which perhaps links their possible involvement in MPN and MCN. On the other hand, Lillehoj and Ceigler [29] give an example where PA and CIT were innocuous when administered alone, but $100 \%$ lethal when given together.

Also, a synergistic effect has been observed with OTA and CIT upon suppressing Concavalin A-induced proliferation of porcine lymphocytes [30]. The same synergistic effect between these mycotoxins has been reported also "in vivo" with poultry, rodents and dogs [31]. However, an "in vitro" synergy between OTA and PA was not observed in the present study (Fig. 1), which can be explained by the specific mechanism of "in vivo" synergistic effect of both mycotoxins

Table 1. The Effect of Mycotoxins OTA, CIT, FB1, PA on Metabolic Activity and Cell Proliferation of PHA-Stimulated PBM

\begin{tabular}{|c|c|c|c|}
\hline Mycotoxins & Level of Mycotoxin Exposure (mg/L) [Mycotoxin Type] & Metabolic Activity of Cells (m.a.c.) (\%) & Cell Proliferation (c.p.) (\%) \\
\hline \hline Mix 1 & $12.5[\mathrm{OTA}]^{\#} ; 125[\mathrm{CIT}, \mathrm{FB} 1, \mathrm{PA}]$ & $89.4 \pm 3.2^{\mathrm{a}, \mathrm{b}, \mathrm{c},{ }^{*}}$ & $32.8 \pm 2.1^{\mathrm{a}, \mathrm{b}, \mathrm{c}, \mathrm{e},{ }^{*}}$ \\
\hline Mix 2 & $12.5[\mathrm{OTA}]^{\#} ; 125[\mathrm{CIT}, \mathrm{FB} 1]$ & $31.2 \pm 1.4^{\mathrm{a}, \mathrm{b}, \mathrm{d}, \mathrm{d}^{*}}$ & $33.1 \pm 2.8^{\mathrm{a}, \mathrm{b}, \mathrm{c},{ }^{*}}$ \\
\hline OTA & $12.5[\mathrm{OTA}]^{\#}$ & $37.6 \pm 1.8^{\mathrm{d}}$ & $42.8 \pm 1.8^{\mathrm{d}, \mathrm{e}}$ \\
\hline CIT & $125[\mathrm{CIT}]$ & $41.8 \pm 2.8^{\mathrm{a}, \mathrm{c}, \mathrm{d}}$ & $44.2 \pm 1.8^{\mathrm{c}, \mathrm{d}}$ \\
\hline FB1 & $125[\mathrm{FB} 1]$ & $55.6 \pm 4.1^{\mathrm{a}, \mathrm{b}, \mathrm{d}}$ & $56.1 \pm 3.2^{\mathrm{a}, \mathrm{b}, \mathrm{d}}$ \\
\hline PA & $125[\mathrm{PA}]$ & $110.2^{\mathrm{b}} \pm 8.5^{\mathrm{b}, \mathrm{c}}$ & $43.1 \pm 2.3^{\mathrm{c}, \mathrm{d}, \mathrm{e}}$ \\
\hline
\end{tabular}

* Significant difference $(\mathrm{p}<0.05)$ compared with the respective value of only OTA-treated cells.

${ }^{\text {a }}$ Significant difference $(\mathrm{p}<0.05)$ compared with the respective value of PA-treated cells.

${ }^{\mathrm{b}}$ Significant difference $(\mathrm{p}<0.05)$ compared with the respective value of CIT-treated cells.

${ }^{c}$ Significant difference $(\mathrm{p}<0.05)$ compared with the respective value of FB1-treated cells.

${ }^{\mathrm{d}}$ Significant difference $(\mathrm{p}<0.05)$ compared with the respective value of mix 1-treated cells.

${ }^{\mathrm{e}}$ Significant difference $(\mathrm{p}<0.05)$ compared with the respective value of Metabolic activity of cells.

\# The concentrations of OTA exposure are 10 times lower, because of the stronger cytotoxic effect of this mycotoxin. The values of m.a.c. and c.p. of OTA-treated cells can not be directly compared with those of CIT, FB1 and PA treated cells, but it can be supposed that they are significantly lower upon considering the 10-fold lower levels of OTA-exposure. m.a.c. - values are the mean ( \pm standard error of 3 samples in 4 different experiments) representing percent change versus control PHA-treated PBM as measured by MTT assay.

c.p. - values are the mean ( \pm standard error of 3 samples in 4 different experiments) percent viable cells versus controls measured after 48 hours using trypan blue staining and a Neubauer haemocytometer (only viable cells were counted).

Mix 1 (with PA) - Mixture 1, containing OTA, CIT, FB1 and PA in relevant concentrations.

Mix 2 (without PA) - Mixture 2, containing OTA, CIT and FB1 in relevant concentrations. 
$[12,13]$ and the MTT assay being inappropriate for cytotoxic evaluation of PA as the same mycotoxin increases metabolic activity of cells [32]. Having in mind that MTT bioassay is a cytotoxicity test based upon the metabolic activity of living cells [33], it is obvious why the cytotoxic potential of PA can not be measured by the same test.

Due to the potent toxic and synergistic effects of OTA and PA [12] or CIT [30], as well as between OTA and FB1 [19, 20], simultaneous exposure to those mycotoxins might be an important factor for development of chronic renal diseases in animals and humans, especially after long-term exposure. A second question then arises, whether such a combination of OTA, FB1, CIT and PA is occurring in food and feed? If this is so, what are the ranges. It has been reported that FB1 and OTA co-occurred in maize from Croatia and other Balkan countries [34]; whereas, FB1 and CIT [4] in addition to OTA and PA [3] are often present in animal feeds from Bulgaria and originating from farms with mycotoxic porcine or avian nephropathy. The concentrations of PA and FB1 in the same feeds are very high in contrast to those of OTA. Similar high levels of OTA and FB1 (up to $40 \mathrm{ppm}$ ) have been also found in some pig feeds by other authors [35], reportedly provoking death as pathological pictures revealed pathological signs of both toxins, e.g. pulmonary oedema, kidney and liver lesions.

Recently, it was shown that PA stimulates the energyproviding physiological processes in Tetrahymena pyriformis cells [32]. In the same experiment, something more interesting was found. When the OD of PA-treated cells was divided by cell concentration it was found that the metabolic activity of single cells (as measured by MTT metabolism per cell) is strongly stimulated by PA above concentrations of $294 \mu \mathrm{M}$. Such findings are in good agreement with our results. However, in the same report there is a statement that the viability of cells is not affected by PA as measured by MTT. This is not correct, because when the metabolic activity of cells is significantly increased by PA, the MTT assay would not be able to give any appropriate information about viability of the cells as measured by dividing OD of mycotoxin-treated wells to OD of control wells (as was calculated by the same authors). In addition, it was found that PA also increases significantly the consumption of oxygen after $24 \mathrm{~h}$ [32]. ATP content was also significantly increased in cells with PA in concentrations $>294 \mu \mathrm{M}$ as stated in the same experiment [32], which however needs a further explanation by the authors. On the other hand, PA-concentrations $>294 \mu \mathrm{M}$ decreased significantly cell concentrations after $24 \mathrm{~h}$, but not after $72 \mathrm{~h}$. Hence, when cell viability is calculated by MTT assay in the same experiment, it appears that there is no difference between PA-treated wells and control wells independently of the fact that the number of living cells in PAtreated wells is significantly lower than in the control wells. This can be explained by increasing MTT metabolism per cell, in addition to activated oxygen consumption and increased ATP concentrations by PA in a dose-dependent manner. Also, the activated metabolism of the cells could lead to degradation of PA to non-toxic metabolites [36], because after $72 \mathrm{~h}$ cell proliferation was not affected by PA. "In vivo" toxicokinetic studies in rats and mice after oral administration of PA show rapid absorption and metabolism of this mycotoxin $[37,38]$.

Therefore, according to our experience and the results obtained by other authors [32], MTT assay is not appropriate to assess the toxic effects of PA. It is known that the reduction of MTT salt to MTT formazan (colored product - crystals) is based on metabolic activity of living cells [33] and is usually used to assess cell viability and cell proliferation. This reaction is catalyzed by mitochondrial succinyl dehydrogenase and requires NADH, which must be supplied by the living cells, thus providing an indication about mitochondrial or glycolytic activities [39]. Actually, the MTT bioassay measures cleavage of yellow tetrazolium salt MTT to yield insoluble purple MTT formazan [40], which collects as crystals within the living cells. The crystals can be dissolved with dimethylsulfoxide [41] to give a coloured solution measured spectrophotometrically. Therefore, this assay is not always appropriate for measuring cell viability and proliferation, especially if metabolic activity of the cells is increased as observed in PA-treated cells [32]. Inhibition of Concavalin Ainduced PBM proliferation by some mycotoxins, including PA and CIT, has been reported recently [30, 42]. In such a way, when cell viability is calculated via MTT assay, it appears that PA-treated cells can significantly increase cell viability irrespective that the number of living cells in PA-treated cell suspensions is usually lower than in untreated controls. Therefore, in order to avoid this contradiction and confusion, it is not correct to maintain the statement that MTT bioassay is used as a parameter for cell viability and number of living cells, as it is stated by many authors [17, 32, 39, 41, 43-46]. The correct statement must be that the MTT bioassay is used as a parameter for mitochondrial or glycolytic metabolic activity of living cells and if that activity of experimental and control cells is the same, it could be supposed that any decrease of metabolic activity in experimental wells could suggest a decreased cell viability or inhibition of cell proliferation. This is very important, because many mycotoxins like OTA, CIT and T-2 have toxic effects on mitochondrial activity and in particular mitochondrial enzymes [47-49] like succinyl dehydrogenase [50]. Other mycotoxins as PA have stimulating effects on mitochondrial activity [32] and can increase metabolic activity of living cells.

Also, it is important to know that relatively minor changes in assay protocols can affect the cytotoxicity of individual toxins and comparative toxicity within a group of toxins [51]. For example, it was established that CIT was more toxic to cells when added at the time of seeding, whereas OTA was more toxic when added $24 \mathrm{~h}$ after cultures were seeded [51]. There is also a report about the cytotoxic effect of PA as measured by MTT assay [41], but in this case the toxic effect was calculated only at $80 \%$ cell viability when incubated for only $20 \mathrm{~h}$. Such a time is probably not sufficient for detecting significant increases of metabolic activity which could compensate for the significant inhibition of cell proliferation $[30,42]$ and cytotoxic effect of PA. In the same report, no toxic effects were reported for aflatoxin B1, T2 and CIT up to the highest concentrations tested $(50 \mathrm{mg} / \mathrm{L})$, which is in disagreement with all other reports [41]. The used cell line (SK cells - Swine kidney cells), is probably also of significant importance. The PBM used in our case are usually very sensitive to most mycotoxins tested via MTT assay [43] and also have well pronounced metabolic activity. In general, the concentrations of OTA and FB1 required to reduce metabolic activity of human PBM by $50 \%$ in our study agree with Charoenpornsook et al. [43], who used the same MTT assay and PHA-stimulation of PBM. In addition, the statement of 
Meky et al. [17] that proliferation of human PBM is not affected by FB1 exposure up to $10 \mathrm{mg} / \mathrm{L}$, as measured by the same MTT assay, is also in good agreement with our results. We do not agree with their statement, that the MTT assay measures PHA-stimulated proliferation of PBM - the term "metabolic activity" would be more appropriate than the term "proliferation" in these cases. Unfortunately, there is no relevant information in the literature about cytotoxic effects of CIT and PA on PBM as measured by the MTT assay; therefore, our data can not be compared to others.

Upon comparing the data from various authors, it is also important to draw attention to the fact that relative concentrations of mycotoxins tested are crucial when designing the experiments. Some of the toxins should be at moderate or high concentrations while the other should be at low concentrations as designed in our experiment (the levels of OTA were 10 times lower than other mycotoxins). This represents more natural concentrations found in test samples.

Since the investigated mycotoxins and their combinations in this study, without PA, have inhibitory effects on metabolic activity and "in vitro" proliferation of PBM, it is possible to have the same effect "in vivo" and perhaps alter antibody production by B-lymphocytes. Immunosuppression of cellular and humoral immune responses has been already reported for OTA $[11,52]$. On the other hand, such immunosuppressive effects have also been reported for FB1 [53, 54], in addition to increased susceptibility of animals to experimental infections [55]. In addition, it is important to recognize that "in vitro" experiments can only demonstrate direct synergistic effects of some mycotoxins, while "in vivo" studies can clearly demonstrate the complex nature of adsorption, distribution, metabolism and excretion of mycotoxins. This is especially so regarding combination of mycotoxins that have a real synergistic effect, as that described for PA and OTA $[12,13]$.

\section{ACKNOWLEDGEMENTS}

This research has been financially supported by European Community under Marie Curie Outgoing International Fellowship in South Africa within $6^{\text {th }}$ European Community Framework Programme (2006-2009) and in part by Department of Science and Technology in South Africa and UK Royal Society Joint Project with Central and Eastern Europe.

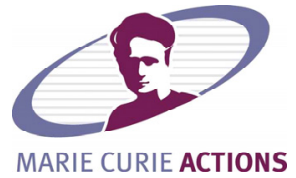

\section{ABBREVIATIONS}

BEN $=$ Balkan Endemic Nephropathy
$\mathrm{CCM}=$ Complete culture medium
$\mathrm{CIT}=$ Citrinin
$\mathrm{DMSO}=$ Dimethylsulphoxide
$\mathrm{FBS}=$ Foetal bovine serum
$\mathrm{FB} 1=$ Fumonisin $\mathrm{B} 1$
$\mathrm{MCN}=$ Mycotoxic chicken nephropathy
MPN $=$ Mycotoxic porcine nephropathy

MTT = 3-(4,5-Dimethylthiazol-2-yl)-2,5-diphenyltetraZolium bromide

$\mathrm{OD}=$ Optical density

OTA $=$ Ochratoxin A

$\mathrm{PA}=$ Penicillic acid

$\mathrm{PBM}=$ Peripheral blood mononuclear cells

PBS $=$ Phosphate buffered saline

PHA $=$ Phytohaemagglutinin-p

\section{REFERENCES}

[1] Dutton MF, Kinsey A. Incidence of mycotoxins and fungi in feedstuffs in Natal in 1995, Mycopathologia 1995; 131: 31-6.

[2] Stoev SD, Hald B, Mantle P. Porcine nephropathy in Bulgaria: a progressive syndrome of complex of uncertain (mycotoxin) etiology. Vet Res 1998; 142: 190-4.

[3] Stoev SD, Daskalov H, Radic B, Domijan A, Peraica M Spontaneous mycotoxic nephropathy in Bulgarian chickens with unclarified mycotoxin aetiology. Vet Res 2002; 33: 83-94.

[4] Stoev SD. Complex Etiology, Prophylaxis and hygiene control in mycotoxic nephropathies in farm animals and humans. Int $\mathrm{J}$ Mol Sci 2008; 9: 578-605.

[5] Voss KA, Riley RT, Norred WP, et al. An overview of rodent toxicities: liver and kidney effects of fumonisins and Fusarium moniliforme. Environ Health Perspect 2001; 109: 259-66.

[6] Stoev SD, Stoeva J, Anguelov G, Hald B, Creppy EE, Radic B. Haematological, biochemical and toxicological investigations in spontaneous cases with different frequency of porcine nephropathy in Bulgaria. J Vet Med Ser A 1998; 45: 229-236.

[7] Krogh P. Mycotoxic Nephropathy. In: Advances in Veterinary Science and Comparative Medicine. Academic Press. New York 1976; 20: pp. 147-170.

[8] Petkova-Bocharova T, Castegnaro M. Ochratoxin A in human blood in relation to balkan endemic nephropathy and urinary tract tumours in Bulgaria. In: Castegnaro M, Plestina R, Dirheimer G, Chernozemsky IN, Bartsch B, Eds. Mycotoxins, Endemic Nephropathy and Urinary Tract Tumours Lyon. IARC 1991; pp. 135-7.

[9] Petkova-Bocharova T, Castegnaro M, Michelon J, Maru V. Ochratoxin A and other mycotoxins in cereals from an area of Balkan endemic nephropathy and urinary tract tumours in Balgaria. In: Castegnaro M, Plestina R, Dirheimer G, Chernozemsky IN, Bartsch B, Eds. Mycotoxins, Endemic Nephropathy and Urinary Tract Tumours. Lyon. IARC 1991; pp 83 - 87.

[10] Stoev SD. The role of Ochratoxin A as a possible cause of balkan endemic nephropathy and its risk evaluation. Vet Hum Toxicol 1998; 40: 352-60.

[11] Stoev SD, Anguelov G, Ivanov I, Pavlov D. Influence of ochratoxin A and an extract of artichoke on the vaccinal immunity and health in broiler chicks. Exp Toxicol Pathol 2000a; 52: 43-55.

[12] Stoev SD, Vitanov S, Anguelov G, Petkova-Bocharova T, Creppy EE. Experimental mycotoxic nephropathy in pigs provoked by a mouldy diet containing ochratoxin A and penicillic acid. Vet Res Commun 2001; 25: 205-23.

[13] Stoev SD, Stefanov M, Denev S, Radic B, Domijan A-M, Peraica M. Experimental mycotoxicosis in chickens induced by ochratoxin A and penicillic acid and intervention by natural plant extracts. Vet Res Commun 2004; 28: 727-46.

[14] Sansing GA, Lillehof EB, Detroy RW, Muller MA. Synergistic toxic effects of citrinin, ochratoxin $A$ and penicillic acid in mice. Toxicon 1976; 14: 213-20.

[15] Shepherd EC, Philips TD, Joiner GN, Kubena LF, Heidelbaugh ND. Ochratoxin A and penicillic acid interaction in mice. J Environ Sci Health B 1981; 16: 557-73.

[16] Micco C, Miraglia M, Onori R, et al. Effect of combined exposure to ochratoxin $\mathrm{A}$ and penicillic acid on residues and toxicity in broilers. La Rav Soc Ital Sci Alliment 1991; 20: 101-8.

[17] Meky FA, Hardie LJ, Evans SW, Wild CP. Deoxynivalenolinduced immunomodulation of human lymphocyte proliferation and cytokine production. Food Chem Toxicol 2001; 39: 827-36. 
[18] Mosmann T. Rapid colorimetric assay for cellular growth and survival: application to proliferation and cytotoxicity assays. J Immunol Methods 1983; 65: 55-63.

[19] Klaric MS, Rumora L, Ljubanovic D, Pepeljnjak S. Cytotoxicity and apoptosis induced by fumonisin B1, beauvericin and ochratoxin A in porcine kidney PK15 cells: effects of individual and combined treatment. Arch Toxicol 2007; 82(4): 247-55.

[20] Creppy EE, Chiarappa P, Baudrimont I, Borracci P, Moukha S, Carratù MR. Synergistic effects of fumonisin $B_{1}$ and ochratoxin $A$ : are "in vitro" cytotoxicity data predictive of "in vivo" acute toxicity. Toxicology 2004; 201: 115-23.

[21] Kubena LF, Edrington TS, Harvey RB, Phillips TD, Sarr AB, Rottinghaus GE. Individual and combined effects of fumonisin B1 present in Fusarium moniliforme culture material and diacetoxyscirpenol or ochratoxin A in turkey poults. Poult Sci 1997; 76: 256-64.

[22] Creppy EE, Röschenthaler R, Dirheimer G. Inhibition of protein synthesis in mice by ochratoxin $\mathrm{A}$ and its prevention by phenylalanine. Food Chem Toxicol 1984; 22: 883-6.

[23] Rahimtula AD, Bereziat JC, Bussachini-Griot V, Bartsch H. Lipid peroxidation as possible cause of Ochratoxin A toxicity. Biochem Pharmacol 1988; 37: 4469-77.

[24] Abado-Becognee K, Mobio TK, Ennamany R, et al. Cytotoxicity of fumonisin B1: implication of lipid peroxidation and inhibition of protein and DNA syntheses. Arch Toxicol 1998; 72: 233-6.

[25] Dragan YP, Bidlack WR, Cohen SM, et al. Implications of apoptosis for toxicity, carcinogenicity, and risk assessment: fumonisin B1 as an example. Toxicol Sci 2001; 61: 6-17.

[26] Gekle M, Schwerdt G, Freudinger R, et al. Ochratoxin A induces JNK activation and apoptosis in MDCK-C7 cells at nanomolar concentrations. J Pharmacol Exp Ther 2000; 293: 837-44.

[27] Petrik J, Zanic'-Grubišic T, Barišic K, et al. Apoptosis and oxidative stress induced by ochratoxin $A$ in rat kidney. Arch Toxicol 2003; 77: 685-93.

[28] Petrik J, MaliT A, BariniT K, et al. Ochratoxin A induces apoptotic and necrotic renal cell death. Croat Chem Acta 2005; 78: 447-53.

[29] Lillehoj EB, Ciegler A. Mycotoxin Synergism. In: Schlessinger D, Ed. Microbiology American Society of Microbiology. Washington. DC 1975; pp. 344-58.

[30] Bernhoft A, Keblys M, Morrison E, Larsen HJS, Flåøyen A. Combined effects of selected Penicillium mycotoxins on "in vitro" proliferation of porcine lymphocytes. Mycopathologia 2004; 158: 441-50.

[31] Koshinsky H, Honour S, Khachatourians G. T-2 toxin inhibits mitochondrial function in yeast. Biochem Biophys Res Commun 1988; 151: 809-14.

[32] Gräbsch C, Wichmann G, Loffhagen N, Herbarth O, Müller A. Cytotoxicity assessment of gliotoxin and penicillic acid in Tetrahymena pyriformis. Environ Toxicol 2006; 21: 111-7.

[33] Slater TF, Sawyer B, Strfiubli U. Studies on succinatetetrazolium reductase systems. III. Points of coupling of four different tetrazolium salts. Biochim Biophys Acta 1963; 77: 383-93.

[34] Jurjevic L, Solfrizzo M, Cvjetkovic B, De Girolamo A, Visconti A. Occurrence of beauvericin in corn from Croatia. Food Technol Biotechnol 2002; 40: 91-4.

[35] Diaz CT, Sogbe E, Ascanio E, Hernandez M. Ochratoxin A and fumonisin B1 natural interaction in pigs. Clinical and pathological studies. Rev Cient Fac Cien V 2001; 314-21.

[36] Chan PK, Hayes AW. "In vitro" metabolism of penicillic acid with mouse-liver homogenate fractions. Food Chem Toxicol 1982; 20: 61-5.

[37] Park DL, Dailey RE, Friedman L, Heath JL. The absorption, distribution, and excretion of 14C-penicillic acid by rats. Ann Nutr Aliment 1977; 31: 919-34.
[38] Chan PK, Hayes AW, Siraj MY, Meydrech EF. Pharmacokinetics of the mycotoxin penicillic acid in male mice: absorption, distribution, excretion, and kinetics. Toxicol Appl Pharmacol 1984; 73: 195-203.

[39] Lewis CW, Smith JE, Anderson JG, Freshney RI. Increased cytotoxicity of food-borne mycotoxins toward human cell lines "in vitro" via enhanced cytochrome p450 expression using the MTT bioassay. Mycopathologia 1999; 148: 97-102.

[40] Altmann ER. Tetrazolium salts and formazans. Prog Histochem Cytochem 1976; 9: 1-56.

[41] Hanelt M, Gareis M, Kollarczik B. Cytotoxicity of mycotoxins evaluated by the MTT-cell culture assay. Mycopathologia 1994; 128: $167-74$.

[42] Keblys M, Bernhoft A, Höfer CC, Morrison E, Larsen HJS, Flåøyen A. The effects of the Penicillium mycotoxins citrinin, cyclopiazonic acid, ochratoxin A, patulin, penicillic acid, and roquefortine C on "in vitro" proliferation of porcine lymphocytes. Mycopathologia 2004; 158: 317-24.

[43] Charoenpornsook K, Fitzpatrick JL, Smith JE. The effects of four mycotoxins on the mitogen stimulated proliferation of bovine peripheral blood mononuclear cells "in vitro". Mycopathologia 1998; 143: 105-11.

[44] Dombrink-Kurtzman MA, Javed T, Bennett GA, Richard JL, Cote LM, Buck WB. Lymphocyte cytotoxicity and erythrocytic abnormalities induced in broiler chicks by fumonisins Ba and B2 and moniliformin from Fusarium proliferatum. Mycopathologia 1993; 124: 47-54.

[45] Reubel GH, Gareis M, Amselgruber WM. Cytotoxicity evaluation of mycotoxins by an MTT-bioassay. Mycotoxin Res 1987; 3: 8596.

[46] Reubel GH, Gareis M, Amselgruber WM. Effects of the Fusarium mycotoxin zearalenone and deoxynivalenol on the mitochondrial methylthiazoltetrazolium-cleavage activity ofmonolayer cells. Toxicol In Vitro 1989; 3: 311-6.

[47] Meisner H, Chan S. Ochratoxin A, an inhibitor of mitochondrial transport system. Biochemistry 1974; 13: 2795-9.

[48] Chagas GM, Campello AP, Kluppel LW. Mechanismof citrinininduced dysfunction of mitochondria. I. Effects on respiration, enzyme activities and membrane potential of renal cortical mitochondria. J Appl Toxicol 1992a; 12: 123-9.

[49] Chagas GM, Oliveira BM, Campello AP, Kluppel LW. Mechanism of citrinin-induced dysfunction of mitochondria. II. Effect on respiration, enzyme activities, and membrane potential of liver mitochondria. Cell Biochem Funct 1992b; 10: 209-16.

[50] Koshinsky HA, Khachatourians GG. Mycotoxicoses. The effects of mycotoxin combinations. In: Hui YH, Gorham JR, Murrell KD, Cliver DO, Eds. Foodborne Disease Handbook. Diseases Caused by Viruses, Parasites, and Fungi. Canada: University of Saskatchewan, Saskatoon 1994; vol. 2: pp. 463-520.

[51] Bondy GS, Armstrong CL. Cytotoxicity of nephrotoxic fungal toxins to kidney-derived LLC-PK1 and OK cell lines. Cell Biol Toxicol 1998; 14: 323-32.

[52] Stoev SD, Goundasheva D, Mirtcheva T, Mantle PG. Susceptibility to secondary bacterial infections in growing pigs as an early response in ochratoxicosis. Exp Toxicol Pathol 2000; 52: 287-96.

[53] Qureshi MA, Hagler WM. Effect of fumonisin B1 exposure on chicken macrophage function in vitro. Poult Sci 1992; 71: 104-12.

[54] Taranu I, Marin DE, Bouhet S, et al. Mycotoxin, fumonisin B1, alters the cytokine profile and decreases the vaccinal antibody titer in pigs. Toxicol Sci 2005; 84: 301-7.

[55] Oswald IP, Desautels C, Laffitte J, et al. The mycotoxin, fumonisin B1, increases intestinal colonization by pathogenic Escherichia coli in pigs. Appl Environ Microb 2003; 69: 5870-4. 